\title{
COLOUR FROM THE PERSPECTIVE OF HADITH: AN OVERVIEW
}

\author{
Mohd Khairul Nizam Zainan Nazri, Nur Saadah bt Hamisan@Khair, Adnan Bin Mohamed Yusoff \\ Fakulti Pengajian Quran dan Sunnah, Universiti Sains Islam Malaysia (USIM) \\ Monika@Munirah Abd Razzak \\ Akademi Pengajian Islam, Universiti Malaya \\ Nurul Jannah Zainan Nazri, Mardiana bt Mat Ishak32 \\ International Islamic University Malaysia
}

\begin{abstract}
Colour is mentioned a few times in the Prophetic Traditions, signifying its values and symbolic representation for the people. The Prophet PBUH highlighted the significance of certain colours by describing his preferred colours for his clothing and he also approved or discouraged the usage of certain colours. Among the colours that are specifically mentioned and found in the hadith are white, red, green, black and yellow. These colours give different connotations as they were used in the Prophet's attires during battles and other occasions; and some bring about specific understanding, as stated by the Prophet PBUH. Interestingly, the use of certain colours as found in the hadith corresponds to that mentioned in the Qur'an. Thus, this paper will observe the discussion among Muhaddithin regarding to the topic of colours in terms of its definition, function, significance and impact on the human life. The variety of meaning and understanding of colours according to different perspectives and cultures will also be discussed. The implications of using specific colours psychologically and scientifically will also be exposed in order to discover the connection between colours in the Prophetic Traditions and in our contemporary life.
\end{abstract}

Key words: Colour, Hadith, the Prophetic Traditions, contemporary.

\section{INTRODUCTION}

Naturally, humans are interested in a variety of colours. God created different colours with different functions and purposes, so that man can feel the pleasure of life in this world. It is unimaginable if the world is filled with only one colour or is colourless. Colours are certainly among the greatest creations of God. Allah SWT said in the Book of revelation: "And among His Signs are the creation of the heavens and the earth, and the diversity of your tongues and colours. In that surely are Signs for those who possess knowledge".

The miraculous nature of colour is affirmed in the revelation of God. It is symbolized by the Muslim scholars that Islam is like a beautiful garden with flowers of various colours. Islam is a religion that is closely connected with the needs of the human soul and nature. It does not hold a hostile position towards any particular colour that is favoured by the people although historically, some type of

\footnotetext{
${ }^{1}$ The Qur'an, Surah al-Rum: 23.
} 
colours are linked or associated with good or evil. It is reported that green has been repeated in the Qur'an eight times ${ }^{2}$ representing the number of gates of Paradise, while the recurrent black colour is mentioned seven times ${ }^{3}$ as the number of gates of hell. ${ }^{4}$ Nevertheless, the perception towards colours is culturally subjective, although some cultures may have a shared perception. For instance, white and green are often associated with good, while black is associated with evil.

We certainly cannot deny the culture-based association that has been given to these colours. ${ }^{5}$ In many societies, good characters like the angels, good people and so on, are often dressed in white. But the evil characters likes magicians and satan will wear dark coloured clothing. So the question is, does Islam also associate these colours with evil and good characters? Did the Prophet Muhammad PBUH love or hate certain colours? Does the Sunnah encourage or forbid Muslims to wear certain colours? Do the colours favored by the Prophet PBUH have certain advantages that can affect the human psychology?

\section{THE SIGNIFICANCE OF COLOUR IN THE PROPHETIC TRADITIONS}

Colour carries a very important role in the human life, for every object in this world, tiny or huge, can be prescribed and may affect our perception or meaning from its colour. ${ }^{6}$ In fact, colour is a concept that helps people to identify the properties of objects and define them in a precise way, because they can develop appropriate connections between events and places, people and objects only through their external appearances and colours. ${ }^{7}$ The significance of colour has been mentioned several times in the Qur'an which shows that Allah acknowledges the different colours, with different purposes, in order to encourage the believers to think and be grateful for His Grace.

In fact, colours are among the creations of God. The Qur'an clearly mentions that Allah SWT said: "And He has pressed into service the things He has created for you in the earth, varying in

\footnotetext{
${ }^{2}$ See the Qur'an, Surah al-An'am: 99; Surah Yusuf: 43; Surah Yusuf: 46; Surah al-Kahf: 31; Surah al-Hajj: 63; Surah Yasin: 80; Surah al-Rahman: 76; and Surah al-Insan: 21.

${ }^{3}$ See the Qur'an, Surah al-Baqarah: 187; Surah Ali-Imran: 106; Surah al-Nahl: 58; Surah Fatir: 27; Surah alZumar: 60; and Surah al-Zukhruf: 17

4 “Al-Alwan wa Ta'thiruhu ala al-Nas", April 7, 2011, http://samera-1968.yoo7.com/t1376-topic, accessed on 13 February 2012.

${ }^{5}$ Choungourian.A. Color Preferences and Cultural Variation. Perceptual and Motor Skills. 26 (1968):12031206.

${ }^{6}$ Rebecca L Alley. Thomas R Alley. The influence of physical state and color on perceived sweetness. The Journal of Psychology,(1998) : 561. See also: Adams, F. M., \& Osgood, C. E.. A cross-cultural study of the affective meaning of color. Journal of Cross-Cultural Psychology, 4(1973):135-156.

${ }^{7}$ Harun Yahya, Allah's Artistry in Colour, Trans.: Mustapha Ahmad, Ed.: Abdassamad Clarke (London, United Kingdom: Ta-Ha Publishers Ltd., 2003), 12 and 22.
} 
colours. Surely, in that is a Sign for a people who take heed". ${ }^{8}$ Consciously or not, we have to realize that colour has been used to shape and describe our lives, our habits, our values, and our feelings throughout the ages. ${ }^{9}$ The holy Qur'an also mentions about the tendency for human beings to wear and choose elegant dresses or things that function as adornment and beautification. ${ }^{10}$ All the clothes and jewelry that the people wear and choose, possess colour. Allah SWT said: "O children of Adam! We have indeed sent down to you raiment to cover your shame, and to be an elegant dress; but the raiment of righteousness - that is the best. That is one of the Signs of Allah, which they may remember" ${ }^{11}$

Similarly, the significance of colour has also been highlighted in the Prophetic Traditions, in which the hadith does not only confirm and affirm Qur'anic laws and principles, but also elaborates the ambivalent, interprets the obscure and ambiguous, and specifies the general statements of the Qur'an. Prophet Muhammad PBUH had a perfect life as a human being and enjoyed his life based upon God's revelation. Although he was chosen as the last Messenger of God, as a normal rational man, his interest in colour like other people cannot be denied. Throughout his life, there are specific colours that caught his eyes and attention such as white and green. Other colours have also been revealed in several hadith indicating different significance to the human life. There have been many analyses conducted based on various psychological tests done by researchers showing the particular significance of each colour. Elliot et al. argued that when a color carries a particular meaning, the mere perception of that color is sufficient to produce affect, cognition, and behavior consistent with that meaning. ${ }^{12}$

The importance of colour in the Prophetic Traditions is shown in the colour of the favorite clothes of the Prophet PBUH. Colours may reflect the identity of a person or even used as a medium of communication, express certain feelings, as well as act as a warning for predators, healing effect ${ }^{13}$, thus having a vital importance for living beings. One of the colours selected by the Prophet PBUH for its sign of purity and cleanliness is white. The Prophet PBUH said: "Wear white clothing because it is more

\footnotetext{
${ }^{8}$ The Qur'an, Surah Al-Nahl: 14.

${ }^{9}$ See: Valdez.P. \& Mehrabian.A.. Effect of Color on Emotions. Journal of Experimental Psychology. General, 123(1994): 394-409.

${ }^{10}$ Abdullah bin Abdul Muhsin al-Turki, Al-Tafsir Muyassar, 153.

11 The Qur'an, Surah al-A'raf: 26.

12 Andrew J. Elliot and Daniela Niesta. Romantic Red: Red Enhances Men's Attraction to Women . Journal of Personality and Social Psychology, v. 95, No. 5, (2008): 1150-1164. See also: Elliot, A. J., Maier, M. A., Moller, A. C., Friedman, R., \& Meinhardt, J. (2007). Color and psychological functioning: The effect of red on performance attainment. Journal of Experimental Psychology: General, 136, 154-168.

${ }^{13}$ Dee, J., \& Taylor, L. Colour therapy: The symbolism, use, and healing effects of colour. (Leicester, England: Silverdale Books, 2002).
} 
tahir and clean and also clothe your dead in it."14 White signifies purity and cleanliness for the reason that if a small stain appears on any white clothing or garment, the spot or dirt will clearly show, in comparison to coloured clothing.

In the same hadith, the Prophet PBUH highlighted that white cloth is to be used after death. Ibn Abbas says that Rasulullah PBUH once said: "Choose white clothing, as it is the best clothing. White clothing should be worn whilst living and the dead should be buried in white."15 This colour becomes a common colour of the cloth used to bury a dead body with, not only in Islam but also in other religions. It will not be accepted if other colours are used in showing respect to the dead. However, there was another coloured-cloth that was used to cover the body of the Prophet PBUH when he passed away as reported by His wife 'Aisha RA, when she said: "When Allah's Apostle died, he was covered with a Hibra Burd (green square decorated garment)."16

Green is a colour that enables a person to feel at bliss, happy joyful and new growth. ${ }^{17}$ It is the colour of nature and the natural environment. A several number of hadith was found to describe the significant meaning of green. Besides white, the Prophet PBUH also loved green clothing. Umm Khalid bint Khalid narrated that the Prophet PBUH was given some clothes including a black Khamisa (a type of outer-clothing). The Prophet PBUH said, "To whom shall we give this to wear?" The people kept silent whereupon the Prophet PBUH said, "Fetch Umm Khalid for me." I (Umm Khalid) was brought carried (as I was small girl at that time). The Prophet PBUH took the Khamisa in his hands and made me wear it and said, "May you live so long that your dress will wear out and you will mend it many times." On the Khamisa there were some green or pale designs (The Prophet PBUH saw these designs) and said, "O Umm Khalid! This is beautiful!"18

Many people believe that every colour has its own special meaning. Similarly the Prophet PBUH had also prescribed a meaning to different colours. ${ }^{19}$ When he expressed his interest in white and green, he also commented on several other colours such as black, red and yellow. For the colour black, there is a hadith proving that wearing black is indeed permissible. For example, the Prophet PBUH had no objection towards the black Khamisa given to Umm Khalid, ${ }^{20}$ and he himself wore a black

\footnotetext{
${ }^{14}$ Narrated by Samurah ibn Jundub $\tau$ from the Messenger $\varepsilon$. Al-Tirmidhi, Shama il Muhammadiyah, no. 14.

${ }^{15}$ Narrated by Ibn Abbas $\tau$ from the Messenger $\varepsilon$. Al-Tirmidhi, Shama il Muhammadiyah, no. 13.

${ }^{16}$ Narrated by 'A'ishah $\tau$ from the Messenger $\varepsilon$. Al-Bukhari, Sahih al-Bukhari, vol. 7, Book 72, no. 705.

${ }^{17}$ ProQuest Education Journals : Current Health 2; Mar 1997; 23, 7 "The wearing of the green”, 2.

${ }^{18}$ Narrated by Umm Khalid $\tau$ from the Messenger $\varepsilon$. Al-Bukhari, Sahih al-Bukhari, Kitab Libas, Bab Khamisah Sawda', vol. 7, Book 72, no. 713.

${ }^{19}$ Hemphill, M. A note on adults' color-emotion associations. Journal of Genetic Psychology, 157 (1996): 275280.

${ }^{20}$ Narrated by Umm Khalid $\tau$ from the Messenger $\varepsilon$. Al-Bukhari, Sahih al-Bukhari, Kitab Libas, Bab Khamisah Sawda', vol. 7, Book 72, no. 713.
} 
turban during his lifetime. Ja'far ibn 'Amr narrated from his father: "I saw the Prophet PBUH on the pulpit wearing a black turban with the extremity loosened between his shoulder-blades."21

In addition, it is permissible to wear red clothes if the red is combined with another colour; it is not permissible to wear plain red, because the Prophet PBUH forbade doing so as mentioned in different narrations of hadith. Al-BarÉ' ibn Ñózib (may Allah be pleased with him) narrated that "The Prophet PBUH forbade us to use soft red mattresses and qasiy - garments with woven stripes of silk."22 Another report from Ibn Abbas, states that: "I was forbidden (to wear) red garments and gold rings, and to recite Qur'an in ruku'.23 'Abdullah ibn 'Amr ibn al- ÑÓî also (may Allah be pleased with them both) said: "A man passed by the Prophet PBUH wearing two red garments and greeted him with salam, but he PBUH did not return the greeting."24

According to the scholars, this hadith indicates that the Prophet PBUH disliked the wearing of garments dyed with safflower (the red dyestuff obtained from safflowers), but he had no objection to garments dyed with clay or other substances, so long as it was not dyed with safflower. ${ }^{25}$ Imam Ibn Hajr was quoted saying: "I believe the wearing of clothing in every colour is permissible except that I would dislike the wearing of that garment that is completely red and also the predominantly red outerwear as this is not the clothing of honourable people in our times. It is always important to consider the practices of the honourable people of every era, as long as there is no $\sin .{ }^{26}$ The colours that the Prophet PBUH prohibited the men from are dark red dyed clothing, those having a saffron colour, and dark yellowish orange. ${ }^{27}$

Regarding the etiquettes of building a mosque, the Prophet PBUH commanded building it among houses, to clean and perfume it in a proper manner, ${ }^{28}$ building it with the intention of it being a place of worshiping Allah, and to beware of using red or yellow for its adornment and decoration. 'Umar RA said: "Build for the people a place to worship Allah, and beware of using red or yellow for adornment and decoration, distracting the people thereby." 29 The wisdom of not using red and yellow is related to

\footnotetext{
${ }^{21}$ Narrated by Ja 'far ibn 'Amr $\tau$ from his father. Muslim, Tirmidhi, Abu Dawud, Nasa'i, and Ibn Majah.

${ }^{22}$ Narrated by Al-BarÉ‘ ibn ÑÓzib $\tau$. Al-Bukhari, Sahih al-Bukhari, no. 5390.

${ }^{23}$ Narrated by Ibn Abbas $\tau$. Al-Nasa'i, Sunan al-Nasa'i, no. 5171. Imam al-Albana said: its isnad is sahih.

${ }^{24}$ Narrated by 'Abdullah ibn 'Amr ibn al-ÑÓ Î $\tau$. Al-Tirmidhi, no. 2731; Abu Dawud, no. 3574. Al-Tirmidhi said: this hadith is hasan gharib with this isnad. This hadith was classed as da'if by Imam al-Albani (Sunan Abu Dawud, 403; Sunan al-Tirmidhi, 334. He said: its isnad is da 'if).

${ }^{25} \mathrm{http}: / /$ muttaqun.com/malehijab.html, accessed on 22 February 2012.

${ }^{26}$ Khalid Saifullah Al Rahmani, "Fiqh of Clothing Color", http://www.mathabah.org/20120208678/articles/fiqhof-clothing-colour.html, accessed on 24 February 2012. See: Ibn Hajar al-'Asqalani, Fath al-Bari.

${ }^{27}$ Ibid. See: Nayl al-Awtar.

28 'A'ishah, may Allah be pleased with her, said: "The Messenger of Allah commanded us to build Masjids among the houses, and to clean them and perfume them." This was recorded by Ahmad and the Sunan compilers with the exception of An-Nasa'i. Ahmad and Abu Dawud recorded a similar report from Samurah bin Jundub.

${ }^{29}$ Narrated by 'Umar $\tau$ from the Messenger $\varepsilon$. Al-Bukhari, Sahih al-Bukhari.
} 
the Prophet's PBUH discouragement against decorating the building of worship as did by the Jews and Christians. Abu Dawud narrated that Ibn 'Abbas said, "The Messenger of Allah said: "I was not commanded to Tashyid the Masjids." 30 Ibn Abbas says that:"Excessive decoration of the masjid is a custom of the Jews and Christians. And it is a tone of grief he predicted." ${ }^{11}$ Anas (may Allah be pleased with him) said, "The Messenger of Allah PBUH said: "The Hour will not come until people show off in building Masjids."32

All colours, whether highlighted or not in the Prophetic Traditions carry different meanings and importance to the human life. It does not mean that we have to use similar colours used by the Prophet PBUH all the time and avoid using other colours. However, it is encouraged to use the colours preferred by the Prophet PBUH as a mean to follow the Sunnah of the Prophet PBUH. The significance of colours from the Sunnah perspective works as a form of branding which is indispensable to the life of any religious followers. All are meant to establish positive identities with the view of achieving God's blessings. Colours intend to enhance the image of Islam to the people, in the most succinct, poetic and crisp language. The Prophetic colours are intended to enhance the image of Islam and portray it in a way that is immediately convincing.

\section{THE COLOURS PREFERRED BY THE PROPHET AND ITS DIFFERENT PERSPECTIVES}

The Prophet PBUH was a man greatly in-tuned with the nature and needs of human beings. Therefore, his consideration of the humanistic needs for colours is highly appreciated and acknowledged by Muslim scholars. Among the Muslim scholars who wrote and discussed the Prophet's awareness of colours is Imam Nawawi who in a special chapter in his book, Riyad al-Salihin wrote on the Sunnah of the Prophet PBUH wearing white clothing, as well as red, green, yellow and black coloured shirts which are to be considered as permissible in practice. ${ }^{33}$

On the other hand, the commands of the Prophet PBUH to his people to wear certain colours as well as prohibitions of certain colours showed that the Prophet PBUH was concerned and aware of the colours surrounding him. The Prophet PBUH was sent not to stop or prevent people from their nature of liking something, but to guide people to choose the best. In general, the colours in the dress worn by men and women are permissible unless it is made forbidden by Islamic teaching or Syari'ah.

\footnotetext{
${ }^{30}$ Narrated by Ibn 'Abbas $\tau$ from the Messenger $\varepsilon$. Abu Dawud, Sunan Abu Dawud.

${ }^{31}$ Narrated by Ibn 'Abbas $\tau$ from the Messenger $\varepsilon$. Abu Dawud, Sunan Abu Dawud.

${ }^{32}$ It was recorded by Ahmad and the compilers of the Sunan, with the exception of Al-Tirmidhi.

${ }^{33}$ Faisal Abdul Aziz al-Mubarak, Tadriz Riyad al-Salihin, $1^{\text {st }}$ ed., (Riyadh: Dar al-ÑÓsimah, 2002: 486-487); AlNawawi, Tahzib Dalil al-Talibin Sharh Riyad al-Salihin,, (El-Mansoura, Egypt: Dar al-Mansurah), v.1, 573.

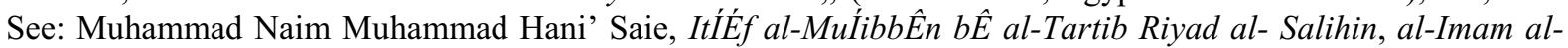
Nawawi, $1^{\text {st }}$ ed, (Cairo: Dar al-Salim, 2007: 239-240)
} 
The Prophetic Traditions have recorded that there is a numbers of colours favoured by the Prophet PBUH. These wisdom or reasons for choosing those particular colours have been discussed by the previous Muslim scholars. For example, Imam al-Nawawi highlighted the topic "About the desirability of white garments..." in his book Kitab Riyad al-Salihin in the chapter $112 .{ }^{34}$

According to the observation of Muslim scholars, white is the best colour as it is chosen by Allah for the Prophet PBUH. It is reported that most of the Prophet's clothing were white as observed by his companions. In a hadith narrated by Abu Dhar RA, he said: "I came to the Prophet PBUH while he was wearing white clothes and sleeping..." 35 In another hadith, 'A'ishah narrated: "Allah's Apostle was shrouded in three Yemenite white Suhuliya (pieces of cloth) of cotton, and in them there was neither a shirt nor a turban." ${ }^{36}$ From this hadith, the Muslim scholars said that it is evident that Allah did not choose the best colour only for His Prophet, ${ }^{37}$ but also for the people in general.

This colour has also been described as the colour of clothing for a good man as told by the Prophet PBUH about Waraqah ibn Naufal. Saydatina Khadijah RA said to the Prophet PBUH, "He believed in you, but died before you appeared as a prophet." Allah's Messenger PBUH then said, "I was shown him in a dream, wearing white clothes, and if he had been one of the inhabitants of Hell he would have been wearing different clothing." 38 Interestingly, the colour white is also associated with the angels, where Imam al-Bukhari recorded in his Sahih al-Bukhari that the colour of the dress of an angel is white. Narrated by Sa'ad: "On the day of the battle of Uhud, on the right and on the left of the Prophet were two men wearing white clothes, and I had neither seen them before, nor did I see them afterwards." 39 Hafiz ibn Hajar in Fath al-Bari said that these two men were Gabriel and Michael. ${ }^{40} \mathrm{Al}-$ Bukhari had placed the hadith in the chapter of white clothes or "Bab al-Thiyab al-Bayda". It shows that Imam al-Bukhari was interested in highlighting the advantages of a white coloured clothing.

Surely, it is highly recommended for men to wear white clothes and to shroud the dead with white cloth. Ibn 'Abbas said that the Prophet PBUH used to say: "Choose white clothing, as it is the best clothing. White clothing should be worn whilst living, and the dead should be buried in white."41 And the Prophet PBUH said, according to Ibn ÑAbbÉs: "Wear white clothes, they are best of your

\footnotetext{
34 Al-NawawÊ, TahzÊEb DalÊl al-ÙÉlibÊn SharÍ RiyÉİ al-ØÉlihÊn, (El-Mansoura, Egypt: DÉr al-ManÉrah), v.1, p.573. See: Muhammad Naim Muhammad Hani' Saie, ItÍÉf al-MuÍibbÊEn b $\hat{E}$ al-TartÊE RiyÉİ al-ØÉliÍÊ $l \hat{E}$ al-ImÉm al-NawawÊ , (Cairo: DÉr al-SalÉm, 2007), $1^{\text {st }}$ ed, p.239-240.

${ }^{35}$ Narrated by Abu Dharr $\tau$ from the Messenger $\varepsilon$. Al-BukhÉrÊ, ØaÍÉÍ al-BukhÉrê, v. 7, no. 717

${ }^{36}$ Al-BukhÉrê, ØaÍÉÍ al-BukhÉrêE, KitÉb JanÉ'iz, BÉb ThiÉb al-Bail lil Kafan, v.2, h.no:354.

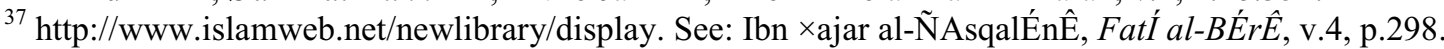

${ }^{38}$ Narrated by ÑÓ'ishah $\tau$ from the Messenger $\varepsilon$. Al-Tirmidhi, Sunan al-Tirmidhi, no. 4623,

${ }^{39}$ Al-BukhÉrÊ, ØaÍÉÍ al-BukhÉrÊE, KitÉb LibÉs, BÉb al-ThiÉb al-Bayİ, vol. 7, no. 716.

${ }^{40}$ Al-BukhÉrÊ, ØaÍÉ Í al-BukhÉrÊ, KitÉb LibÉs, BÉb al-ThiÉb al-Bayİ, vol. 10, p. 295.

${ }^{41}$ Narrated by Ibn ÑAbbÉs $\tau$ from the Messenger $\varepsilon$. Al-Tirmidhi,ShamÉ'il MuÍammadiyah, no. 13.
} 
clothes, and shroud your dead in them...".42 Aĺmad and IsíÉq added: "It is preferable for us if one is enshrouded in a white shroud of good quality". ${ }^{43}$ The use of white cloth to enshroud the dead body is not only practiced by Muslims. It is also a ritual of other cultures in respecting the deceased. In other words, white is traditionally related to death and mourning in most of the cultures of the world, such as in parts of Africa, China, India and many tropical countries. This arises from the belief that death is seen as a beginning and that white represents a sense of purity that the deceased brings into the next life. ${ }^{44}$

In addition to that, it is highly recommended to wear white ihram for men and a wrapper robe during pilgrimage. As mentioned in another hadith narrated by Abu DhÉr: "I came to the Prophet while he was wearing white clothes and sleeping. Then I went back to him again after he had got up from his sleep. He said, "Nobody says: 'None has the right to be worshipped but Allah' and then later on he dies while believing in that, except that he will enter Paradise." I said, "Even if he had committed illegal sexual intercourse and theft." I said, "Even if he had committed illegal sexual intercourse and theft?" He said. "Even If he had committed illegal sexual intercourse and theft," I said, "Even if he had committed illegal sexual intercourse and thefts." He said, "Even if he had committed illegal sexual intercourse and theft, despite Abu Dharrs dislike." Abu 'Abdullah said, "This is at the time of death or before it if one repents and regrets and says 'None has the right to be worshipped but Allah. He will be forgiven his sins." 45

For clothing, white is desirable and suitable for men and women regardless of their age and physical appearance, but clothing that is for fame should be avoided in any colour. ${ }^{46}$ White was chosen because they believed that it expresses purity, innocence, wholeness, completion and perfection as acknowledged by psychologists. ${ }^{47}$ It does not contradict with a saying of Ibn ÑAbbÉs: "Wear white clothes, they are the purest and best." $48 \mathrm{~A}$ poem by a Muslim scholar also came with an analysis that "whiteness carry very small sin and error."49 In addition to this, a research conducted shows that colour white contains all the other colours in the spectrum, showing that the people who wear white have a positive, well-balanced and optimistic personality. 50

\footnotetext{
${ }^{42}$ Sunan Abu Dawud, Bab Fi Ba'idh, v.11, p.86. h.no:3539.

${ }^{43}$ Al-Husaini, Abdul Majid Hasyim, Syarí RiyÉİ al-ØÉliÍÊn, (Beirut: DÉr al-JÊl, 2005), $1^{\text {st }}$ ed, p. 577.

${ }^{44} \mathrm{http}: / / \mathrm{www} . c o l o r m a t t e r s . c o m /$ color-matters-for-kids/color-and-what-you-wear, accessed on 22 February 2012.

${ }^{45}$ Al-BukhÉrê, ØaÍÉÍ al-BukhÉrế, KitÉb LibÉs, BÉb al-ThiÉb al-Bayİ, vol.7, no. 717.

${ }^{46}$ Al-Husaini, p.456. See: Color the silent language. Paint \& Coatings Industry; Sep 2002; 18, 9; ABI/INFORM Trade \& Industry p. 78

${ }^{47} \mathrm{http}: / /$ www.empower-yourself-with-color-psychology.com/color-white.html, accessed on 22 February 2012.

${ }^{48}$ Ibid.

${ }^{49}$ Al-Husaini, p.456.

${ }^{50}$ http://library.thinkquest.org/C004179/significance.htm, accessed on 22 February 2012.
} 
In other cultures, ${ }^{51}$ white is the colour worn by American brides as well as in Japan, while brides in much of Asia wear red. The West also believes that white is associated with the colour of angels and represents goodness in personality. In Chinese culture, colours correspond with the five primary elements, the directions, and the four seasons. White is associated with metal, west, and autumn. Universally, a white flag is recognized as a symbol of truce or a signal of peaceful surrender. Leonardo Da Vinci also acknowledged the importance of white more than any other colours by saying: "The first of all single color is white ... We shall set down white for the representative of light, without which no color can be seen; yellow for the earth; green for water; blue for air; red for fire; and black for total darkness." 52

Another favourite colour of the Prophet PBUH is green. A number of hadith was found to describe the significance of the colour green. Besides white, green was chosen to be the colour of the Prophet's dress in which he was pleased with that kind of colour. Umm Khalid bint Khalid narrated that the Prophet PBUH was given some clothes including a black Khamisa (a type of outer-clothing). The Prophet PBUH said, "To whom shall we give this to wear?" The people kept silent whereupon the Prophet PBUH said, "Fetch Umm Khalid for me." I (Umm Khalid) was brought carried (as I was small girl at that time). The Prophet PBUH took the Khamisa in his hands and made me wear it and said, "May you live so long that your dress will wear out and you will mend it many times." On the Khamisa there were some green or pale designs (The Prophet PBUH saw these designs) and said, "O Umm Khalid! This is beautiful!"53

As he had a liking for the colour green, the Prophet PBUH was found by the companions with green garment over him, as reported by Abu Rimthah RA: "I went with my father to the Prophet PBUH and saw two green garments over him". ${ }^{4}$ It shows that he himself chose green to be the colour of his clothes. The hadith shows that the companion of the Prophet PBUH, Abi Rimthah had seen the prophet wearing a green coloured shirt. Ibn Battal in his explanation of the hadith said: "Green clothing is to dress the people of Paradise" and he added "it is enough of this honor for its greenery and the encouragement to wear it"55 This colour has also been mentioned in the Qur'an to be the colour of the garment of the dwellers of Paradise, Allah said: "It is these who will have Gardens of Eternity beneath which streams shall flow. They will be adorned therein with bracelets of gold and will wear green

\footnotetext{
${ }^{51}$ See: Choungourian.A.(1968). Color Preferences and Cultural Variation. Perceptual and Motor Skills. 26. p. 1203-1206.

${ }^{52} \mathrm{http} / / / \mathrm{www}$.sensationalcolor.com/color-messages-meanings/color-meaning-symbolism-psychology/all-aboutthe-color-white.html, accessed on 22 February 2012.

${ }^{53}$ Narrated by Umm KhÉlid $\tau$ from the Messenger $\varepsilon$. Al-BukhÉrÊ, ØaÍÉÍ al-BukhÉrêE, vol. 7, Book 72, no. 713.

${ }^{54}$ Narrated by Abu Rimthah $\tau$ from the Messenger $\varepsilon$. Sunan al-Tirmidhi, Bab MÉ JÉ’a fÊ Thaub Akhİar, v.10, .no. 2737, p. 9. Sunan Abi Dawud, Book 9, no. 1678.

${ }^{55}$ Ibnu Bailḯl, SyaraÍ ØaÍẾ́ al-BukhÉrê, vol. 17, p.122.
} 
garments of fine silk and heavy brocade, reclining therein upon raised couches. How good the reward and how excellent the place of rest!"56 Another Qur'anic verse mentions: "Upon them will be green garments of fine silk and heavy brocade, and they will be adorned with Bracelets of silver; and their Lord will give to them to drink of a Wine Pure and Holy."57

In addition to this, the Messenger of God PBUH gave an analogy on the significance of the colour green, as mentioned in a long hadith. Narrated by Ñlkrimah: RifaÑa divorced his wife whereupon ÑAbd al-Raĺman ibn al-Zubayr al-Qurazi married her. Ñó'ishah said that the lady (came), wearing a green veil (and complained to her (ÑÓ'ishah) of her husband and showed her a green spot on her skin caused by beating). It was the habit of ladies to support each other, so when Allah's Apostle came, Ñó'ishah said, "I have not seen any woman suffering as much as the believing women. Look! Her skin is greener than her clothes!" When ÑAbd al-Ralman heard that his wife had gone to the Prophet PBUH, he came with his two sons from another wife. She said, "By Allah! I have done no wrong to him but he is impotent and is as useless to me as this," holding and showing the fringe of her garment. ÑAbd alRaĺman then said, "By Allah, O Allah's Apostle! She has told a lie! I am very strong and can satisfy her but she is disobedient and wants to go back to RifaÑa." Allah's Apostle said to her, "If that is your intention, then know that it is unlawful for you to remarry Rifa'a unless ÑAbd al-Raĺman has had sexual intercourse with you." Then the Prophet PBUH saw two boys with ÑAbd al-Ralman and asked (him), "Are these your sons?" On that ÑAbd al-Raĺman said, "Yes." The Prophet PBUH said, "You claim what you claim (i.e.. that he is impotent)? But by Allah, these boys resemble him as a crow resembles a crow," 58

The advantage of the green colour also has been stated in another hadith as narrated by Muslim. AbË SaÑ̂̂Ed al-KhudrÊ reported that Allah's Messenger PBUH said: "The world is sweet and green (alluring) and verily Allah is going to install you as vicegerent in it in order to see how you act. So avoid the allurement of women: verily, the first trial for the people of Isri'll was caused by women." And in the hadith transmitted on the authority of Ibn BashshÉr continued that: "So that He should see how you act." ${ }^{59}$ Syeikh ÑAbd al-KarÊm Khudayr explained that "...the best colour is green, this world consists of people and are attracted and deceives the worldly things, seems like a sweet and green, or else such as this does not fool those who know the fact of the world, and they cursed; but they seem people like this sweet and green, for rights to warn them..."60

\footnotetext{
${ }^{56}$ The Qur'Én, SËrah al-Kahf: 31.

57 The Qur'Én, SËrah al-InsÉn: 21.

${ }^{58}$ Al-BukhÉrÊ, ØaÎẾ al-BukhÉrÊ, KitÉb LibÉs, BÉb al-ThiÉb al-Khudr, vol. 7, no. 715.

${ }^{59}$ Muslim, ØaÍÉĺ Muslim, KitÉb RiqÉq, The Majority In Paradise Would Consist Of The Poor Pious Persons And The Majority Of The Denizens Of Hell Would Consist Of Women, And The Trial By Means Of Women, no:6606, v.12, p. 386

${ }^{60} \mathrm{http} / / /$ www.alfeqh.com, accessed on 18 February 2012.
} 
Most of the Western cultures accept that green is a 'lucky' colour. It is also the colour that represents a new birth, new growth, regeneration, nature and environmental awareness. ${ }^{61}$ Instinctively, green evokes a sense of relaxation, comfort and quietness. The easiest colour for the eye to see and therefore the most restful of all the colours. Green is the colour of concentration and relaxation. ${ }^{62}$

As one of the colours of the traffic light, green is used worldwide to symbolize safety. Although green is a forbidden colour in Indonesia, it is said that green is the most tranquil colour to the human eye. That is the reason why it is used as a symbol to protect the environment and reduce waste or pollution. Furthermore, green is considered as the color of peace and ecology, and also symbolizes wealth and property in many cultures. ${ }^{63}$

Understanding the symbol and character of colours from different perspectives is essential in communicating with other cultures. These differences facilitate better interaction with one another by respecting each other's ascribed values and meaning of colours. Although Islam is based on revelation, it is permissible to find new information and knowledge from other religions or cultures, in order to live peacefully and harmoniously.

\section{PSYCHOLOGICAL IMPLICATION OF THE PROPHET'S PREFERED COLOURS}

Colours have a special relation with human psychology. It is one of the most powerful elements that have impact on the human life, habitually in unconscious and mysterious ways. It has tremendous and expressive qualities which can affect man psychologically. Several studies have explored the positive and negative implications of colours from the aspects of psychology and physiology. It is shown in a study done by the American Institute for Biosocial Research that colours not only psychologically affect behavior, but also have a direct physiological impact. Mr. Faber Birren, a colour consultant said: "The magical properties of light and color, granted by men since the earliest of times, accepted, renounced and accepted again through the ages, have forever held fascination. It would be delightful, of course, if a thing of such psychological beauty - color - also held a mundane role in human physiological wellbeing." 64

\footnotetext{
${ }^{61}$ See: ProQuest Education Journals : Current Health 2; Mar 1997; 23, 7 "The wearing of the green" p.2 and http://www.empower-yourself-with-color-psychology.com/cultural-color.html, accessed on 22 February 2012.

${ }^{62}$ See: Color the silent language. Paint \& Coatings Industry; Sep 2002; 18, 9; ABI/INFORM Trade \& Industry p. 78

${ }_{63} \mathrm{http} / /$ www.sensationalcolor.com/color-messages-meanings/color-meaning-symbolism-psychology/all-aboutthe-color-green.html, accessed on 22 February 2012. See: Aslam, M. M. (2006). Are you selling the right colour? A cross-culturalreview of colour as a marketing cue. Journal of Marketing Communications, 12, 15-30.

${ }^{64}$ Lindsay Gruson, "Color Has a Powerful Effect on Behavior: Researchers Assert", The New York Times, published on October 19, 1982, http://www.nytimes.com/1982/10/19/science/color-has-a-powerful-effect-onbehavior-researchers-assert.html?pagewanted=all, accessed on 22 February 2012.
} 
Due to the positive effects of colour, it becomes a new alternative in healing and treatment which is known as colour therapy. Occasionally, colour therapy, which is also called chromotherapy, ${ }^{65}$ colorology or cromatherapy, is a complementary therapy for which there is evidence of its application dating back to thousands of years to the ancient cultures of Egypt, China and India. This therapy believes that colour is simply light of varying wavelengths, thus each colour has its own particular wavelength and energy. The energy relating to each of the seven spectrum colours of red, orange, yellow, green, blue, indigo and violet, resonates with the energy of each of the seven main chakras or energy centres of the body. It is used to re-balance and/or stimulate these energies by applying the appropriate colour to the body and therefore re-balances the energy of the body. In addition to this, Colour Therapy is a totally holistic and non-invasive therapy which is safe to use alone or alongside with any other therapy whether orthodox medicine or another complementary therapy and is safe for adults, children and animals too. ${ }^{66}$

There is no doubt that colour has its impact on psychology. Each colour has a frequency of its own and when it is selected through the blasted affect of the eye, its frequencies is transmitted from the eye to the brain and creates different effects to the brain. Remarkably, market researchers have done extensive studies exploring the emotional responses of people to colour and its implication on the human life. Some of these responses seem to be powerful and fairly universal. However, all of this information is culturally biased, for the meaning of a particular colour is different and depends on cultural traditions and circumstances.

Psychologically, each colour can portray a different message. It is not static energy but instead the various colours can be seen as a form of non verbal communication. The meaning of a colour can change from one day to the next according to the individual. For example, a person may choose to wear red one day and this may indicate they are ready to take action, or they may be passionate about what they are going to be doing that day, or again it may mean that they are feeling angry that day, on either a conscious or subconscious level. ${ }^{67}$ From this point of view, the psychology of colour can be applied to the particular colours that the Prophet PBUH liked or discouraged, as found in the Prophetic Traditions. Indeed, the Prophet PBUH was sent not to prevent people from the natural gifts from the

\footnotetext{
${ }^{65}$ It is said that a therapist trained in chromotherapy can use light in the form of color to balance "energy" wherever a person's body be lacking, whether on physical, emotional, spiritual, or mental levels. The practice has been labelled pseudoscientific by some of its critics. See: http://en.wikipedia.org/wiki/Chromotherapy, accessed on 22 February 2012.

${ }^{66} \mathrm{http}: / /$ www.colourtherapyhealing.com/colour_therapy/what_is_colour_therapy.php, accessed on 23 February 2012.

${ }^{67} \mathrm{http} / / /$ www.empower-yourself-with-color-psychology.com/meaning-of-colors.html, accessed on 23 February 2012.
} 
Creator, but to guide people to choose the best. His actions during his lifetime were not based on lust or desire, for he is guided by God's revelation. 68

Only certain colours are highlighted in the Prophetic Traditions such as white, green, black, red and yellow, as previously mentioned. While the Prophet PBUH preferred using white as the colour of his clothing and encouraged using white cloth for performing pilgrimage and shrouding the dead body, psychologists believe that white is the colour at its most complete and pure. It symbolizes a new beginning like a baby born into the world with a perfect balance of white, and ready to imprint their lives with all the colours of the spectrum from all their life experiences. ${ }^{69}$ Islam also believes that a new born baby is pure from any sin as mentioned by the Prophet PBUH: "Every child is born on Fitrah, then his parents make him a Jew, a Christian, or a Magian just as the animal produces its baby with perfect limbs. ${ }^{70}$

Psychologically, the basic feature of white is equality, implying fairness and impartiality, neutrality and independence. White is totally reflective, promotes openness, growth and creativity. It is the colour of protection and encouragement, offering a sense of peace, calmness, comfort and hope, helping to alleviate emotional upsets. White is frequently used in many medical practices such as dental surgeries and doctors' rooms as an indication of cleanliness and efficiency; however it also can give the feeling of sterility and coldness of emotions and may lead patients to think that the doctor or dentist will not relate to them on an emotional and personal level. It can be too clinical and sterile. ${ }^{71}$ In the hospital, white can be used in any parts of the building. When it is used as the colour of the floor in the hospital, it can stabilize the body and create inner peace for the patients but at the same time, it can also develop a feeling of emptiness and isolation. ${ }^{72}$

White can also be beautifully combined with green, to be used as the colour of buildings or clothes. Green is the colour of balance and harmony. From the psychological perspective, it is the great balancer of the heart and the emotions, creating equilibrium between the head and the heart. It is also the colour of growth, the colour of spring, of renewal and rebirth. It renews and restores depleted energy. It is the sanctuary, away from the stresses of modern living, restoring us back to a sense of well

\footnotetext{
68 See: the Qur'Én, al-Najm: 3-4.

${ }^{69} \mathrm{http}: / /$ www.empower-yourself-with-color-psychology.com/color-white.html, accessed on 23 February 2012.

${ }^{70}$ Al-BukhÉrế, ØaÍẾ al-BukhÉrêE, Book on funeral, no. 1358; Muslim, ØaÍÉÍ Muslim, Book on Destiny, no. 2658; Al-Tirmidhi, Sunan Tirmidhi, no. 2138; AbË DÉwud, Sunan AbÊ DÉwud, Book on al-Sunnah, no. 4714; AÍmad, Musnad AÍmad, vol. 2, p. 315; and MÉlik, MuwaIIIa' MÉlik, Books on Funeral, no. 569.

${ }^{71} \mathrm{http} / /$ www.empower-yourself-with-color-psychology.com/color-white.html, accessed on 23 February 2012.

72 Ayu Wandira and Septana B Pribadi, "Kajian Aplikasi Warna Interior Rumah Sakit Ibu dan Anak Pada Psikologi Pasien Anak", Modul, Vol.11, No.2 Agustus 20122, Diponegoro University, Institutional Repository (UNDIP-IR), pp. 76-77. http://eprints.undip.ac.id/32472/1/3.KAJIAN_APLIKASI_INTERIOR_RS_septana.pdf, accessed on 23 February 2012.
} 
being. This is why there is so much of this relaxing colour on the earth and being an emotionally positive colour, it gives one the ability to love and nurture oneself and others unconditionally. ${ }^{73}$ In the hospital, green can be used to heal pain and reduce stress. It also can develop the feeling of acceptance and strength for patients, physically and emotionally. ${ }^{74}$

As the only colour specifically highlighted in the Qur'an, green is actually produced from a combination of blue and yellow. The colour green encompasses the mental clarity and optimism of yellow with the emotional calm and insight of blue, inspiring hope and a generosity of spirit which are not available from other colours. ${ }^{75}$ This colour is also related to the natural environment. The Prophet PBUH had mentioned green as a good colour for a healthy plant which symbolizes the healthy faith of a believer. He said: "The example of a believer is like a green tree, the leaves of which do not fall." believed that green is closely related to Islam for the reason that it is used as the flag colour of many Muslim countries in the Middle East. It is also the colour of the dome of the Prophet's Mosque (Masjid al-Nabawi). The dome is located over the grave of the Prophet PBUH and dates back to the seventh century $\mathrm{AH}$. It was built during the reign of Sultan Qalawoon, and at first it was the colour of wood, then it became white, then blue, then green, and it has remained green ever since. ${ }^{77}$

In addition to white and green, black was also mentioned several times in the Prophetic Traditions. The Prophet PBUH had no objection towards this colour and was also reported to have worn black turban during his lifetime. For this reason, the meaning of black that symbolizes death and evil is not accepted in Islam even though it is used as the traditional colour of mourning in Western cultures. The Islamic jurists said that the use of black clothing to mourn and express grief for the deceased is not permissible, as mentioned in Alamghiri "Wearing black coloured clothing is not permissible with the intent of mourning over the dead." 78

According to psychologists, black absorbs negative energy. It is the colour of the hidden, the secretive and the unknown, creating an air of mystery. Simultaneously, black means power and control, hanging on to information and things rather than giving out to others. It helps to protect a person from external emotional stress. It creates a barrier between itself and the outside world, providing comfort while protecting its emotions and feelings, and hiding its vulnerabilities, insecurities and lack of self

\footnotetext{
${ }^{73} \mathrm{http}$ ://www.empower-yourself-with-color-psychology.com/color-green.html, accessed on 23 February 2012.

${ }^{74}$ Ayu Wandira and Septana B Pribadi, p. 74-77.

${ }^{75} \mathrm{http}$ ://www.empower-yourself-with-color-psychology.com/color-green.html, accessed on 23 February 2012.

${ }^{76}$ Narrated by Ibn ÑUmar $\tau$ from the Messenger $\varepsilon$. Al-BukhÉrÊE, ØaÍÉÍ al-BukhÉrêE, Book 73: Good Manners and Form (al-Adab), Vol. 8, no. 143.

${ }_{77}^{7 t t p}: / /$ www.islamqa.com/en/ref/110061, accessed on 23 February 2012.

${ }^{78}$ Khalid Saifullah Al Rahmani, "Fiqh of Clothing Color", http://www.mathabah.org/20120208678/articles/fiqhof-clothing-colour.html, accessed on 24 February 2012.
} 
confidence. In addition to this, black implies self-control and discipline, independence and a strong will, as well as the impression of authority and power. Teenagers often have a psychological need to wear black during the stages of transition from the innocence of childhood to the sophistication of adulthood. It signifies the ending of one part of their life and the beginning of another, allowing them to hide from the world while they discover their own unique identity. It is important that they go through this stage but it becomes a concern should it continue into adulthood, that is, to wear black to the exclusion of other colours. Too much black can cause depression and mood swings and create a negative environment. Therefore, it is advised to combine black and white, for it can create an argumentative atmosphere. It is best to use some colours with black to lighten and brighten its energy. ${ }^{79}$

Unlike these colours which are favoured by the Prophet PBUH, red and yellow were treated with less interest and with a reason. Although the Prophet Muhammad PBUH was chosen as the last Messenger of God, he is still a human being who has feelings and interests like other human beings, but guided by the revelation of God. ${ }^{80}$ According to the reports by Muslim scholars, the Prophet PBUH never prohibited the usage of red and that he merely expressed his dislike through his indirect actions. Nevertheless, psychological research shows that red signifies a pioneering spirit and leadership qualities, promoting ambition and determination. 81

The colour red 82 is a warm and positive colour that is associated with human physical needs and the will to survive. Red exudes a strong and powerful masculine energy. It indicates a strong-will, drive and persistence. It can give confidence to those who are shy or lacking in will power. However, being surrounded by too much red can cause us to become irritated, agitated and ultimately angry. Although it can positively promote vivacity with its useful energy, it can be negatively used to express anger and aggression. Too little of red can develop a feeling of becoming cautious, manipulative and fearful. In Eastern cultures such as China, red is the colour for good 'luck' and is traditionally used for weddings. In the Indian culture, it symbolizes purity and is often used in their wedding gowns. ${ }^{83}$

As for the colour yellow, it has been mentioned together with red in the hadith of the Prophet $\mathrm{PBUH}$. Although there is no direct prohibition to use red alone, red and yellow are mentioned together in the same narration that discouraged their usage as the colour of the mosque. ${ }^{84} \mathrm{It}$ is because at that

\footnotetext{
${ }^{79} \mathrm{http}: / /$ www.empower-yourself-with-color-psychology.com/color-black.html, accessed on 23 February 2012.

${ }^{80}$ Allah says: "Say: "I am but a man like yourselves, (but) the inspiration has come to me”, the Qur'Én, SËrah al-Kahf: 110.

${ }^{81}$ See: Hill, R. A., \& Barton, R. A. (2005). Red enhances human performance in contests. Nature, 435, 293.

${ }^{82}$ See: Greenfield, A. B. (2005). A perfect red: Empire, espionage, and the quest for the color of desire. New York: HarperCollins.

${ }^{83} \mathrm{http}: / /$ www.empower-yourself-with-color-psychology.com/color-red.html, accessed on 23 February 2012.

${ }^{84}$ Narrated by ÑUmar $\tau$ from the Messenger $\varepsilon$. Al-BukhÉrÊ, ØaÍÉÍ Al-BukhÉr $\hat{E}$,
} 
time, people from other religions especially Jews and Christian used red and yellow to decorate and beautify their places of worship. ${ }^{85}$ So, it was an order to abstain from imitating actions of the disbelievers, in order to protect the sanctity of the mosque as the place of worship of the one and only God. This prohibition is not related to any of the findings of the psychological studies.

Psychologists however believe that yellow is related to acquired knowledge. It is the colour that resonates with the left or logic side of the brain, stimulating human mental faculties and creating mental agility and perception. Being the lightest hue of the spectrum, the colour psychology of yellow is uplifting and illuminating, offering hope, happiness, cheerfulness and fun. It inspires original thought and inquisitiveness. It is a creative colour which creates new ideas and aids in finding new ways of doing things. It is the practical thinker, not the dreamer. Yellow helps with decision making as it relates to clarity of thought and ideas, although it can often be impulsive. Yellow helps us focus, study and recall information, which is useful during the time of examination. However, yellow can produce anxiety as it is fast moving and can cause us to feel agitated. 86

The meaning of colours based on psychological studies can help us to better understand the language of colours in addition to following the permissibility and prohibition of particular colours as found in the Prophetic Traditions and as discussed by Muslim scholars. However, Islamic jurists state that "there is no objection to any colour of clothing" 87 as long as it is not against the Islamic teaching. Colour might be a wonderful thing to observe in life, but it can also be harmful if it is used according to lust and desires. Therefore, following the Sunnah of the Prophet PBUH in selecting colours relevant to our daily lives, is the best choice, as we match the right colour to be used at the right place and time.

\section{CONCLUSION}

Colours are among the great bounties and grace from Allah the Almighty. He purposely created colour as He did with any other creations of His in order to allow us to know Him and ponder upon what He has created. Allah sent His last Messenger, Prophet Muhammad PBUH not only to convey the order to worship Allah as the only Lord but to show the beauty of Islam which encompasses every aspects of human life including the significance of colour. The Prophet PBUH revealed his preferred colours during his lifetime, and the companions then analyzed it and reported it in the proper traditions, forming a source of reference for Muslims to follow.

\footnotetext{
${ }^{85}$ Narrated by Ibnu ÑAbbÉs $\tau$ from the Messenger $\varepsilon$. AbË DÉwud, Sunan AbÊ $D E ́ w u d$.

${ }^{86} \mathrm{hhttp}: / /$ www.empower-yourself-with-color-psychology.com/color-yellow.html, accessed on 23 February 2012.

${ }^{87}$ Khalid Saifullah Al Rahmani, "Fiqh of Clothing Color", http://www.mathabah.org/20120208678/articles/fiqhof-clothing-colour.html, accessed on 24 February 2012. See: al-DËr al-MukhtÉr.
} 
Without a doubt, the colours that were favoured by the Prophet PBUH have a great impact on human beings, spiritually, psychologically, mentally and physiologically. These colours do not contradict the findings gathered by psychologists or physiologists in their studies even though colours may mean different things to different cultures. This variety of perception makes other cultures even more unique and interesting especially in our effort to know each other. Allah created men from different ethnic groups, tribes, cultures, and languages, so that we may know each other and appreciate His diverse creation in the universe. He mentions in the Qur'Én: "O mankind! We created you from a single (pair) of a male and a female, and made you into nations and tribes, that ye may know each other (not that ye may despise (each other). Verily the most honoured of you in the sight of Allah is (he who is) the most righteous of you. And Allah has full knowledge and is well acquainted (with all things)."88

The perspective of Sunnah towards the importance of colour in our life should be given attention. Although it is not a big issue or problem among Muslims, it is always good to follow the Prophet PBUH and to show the disbelievers that Islam is a beautiful way of life. Islam is a comprehensive religion and the Prophet PBUH guided almost every single aspect of the human life, for he was the final chosen Messenger of Allah. While white, green, black, red and yellow as mentioned in the Prophetic Traditions are only parts of hundreds of colours in this world, this study may be useful in helping us practice the Sunnah of the Prophet PBUH and thus obtain the blessings of God.

\section{BIBLIOGRAPHY}

Ayu Wandira and Septana B Pribadi, "Kajian Aplikasi Warna Interior Rumah Sakit Ibu dan Anak Pada Psikologi Pasien Anak", Modul, Vol.11, No.2 Agustus 20122, Diponegoro University, Institutional Repository (UNDIP-IR), http://eprints.undip.ac.id/32472/1/3.KAJIAN_APLIKASI_INTERIOR_RS-_septana.pdf, accessed on 23 February 2012.

Al-Husayni, Abdul Majid Hashim, Sharh Riyad al-Salihin, 1st ed, (Beirut: Dar al-Jayl, 2005:456)

Al-NawawÊ, TahzÊb DalÊl al-ÜÉlibÊn Sharí RiyÉl al-ØÉlihÊn, (El-Mansoura, Egypt: DÉr al-ManÉrah), v.1, p.573.

Faisal Abdul Aziz al-Mubarak, Tadriz Riyad al-Salihin, 1st ed. (Riyadh: DÉr al-ÑÓsimah, 2002),

Harun Yahya, Allah's Artistry in Colour, London, (United Kingdom: Ta-Ha Publishers Ltd., 2003), Trans.: Mustapha Ahmad, Ed.: Abdassamad Clarke.

${ }^{88}$ The Qur'Én, SËrah al-×ujurÉt:13. 
Khalid Saifullah Al Rahmani, "Fiqh of Clothing Color", http://www.mathabah.org/20120208678/articles/figh-of-clothing-colour.html, accessed on 24 February 2012

Lindsay Gruson, "Color Has a Powerful Effect on Behavior: Researchers Assert", The New York Times, published on October 19, 1982, http://www.nytimes.com/1982/10/19/science/color-has-apowerful-effect-on-behavior-researchers-assert.html?pagewanted=all, accessed on 22 February 2012.

Muhammad Naim Muhammad Hani' Saie, ItíÉf al-MulibbÊn bi al-Tartib Riyad al-Salihin li al-Imam alNawawi, 1st ed, (Cairo: Dar al-Salim, 2007:239-240)

Mawsu'ah al-'Alam Islamiy, $1^{\text {st }}$ ed., (NPP Amman Jordan, 1994)

"Al-Alwan wa Ta'thiruhu ala al-Nas", April 7, 2011, http://samera-1968.yoo7.com/t1376-topic, accessed on 13 February 2012.

Journal :

Adams, F. M., \& Osgood, C. E. A cross-cultural study of the affective meaning of color. Journal of Cross-Cultural Psychology, 4, (1973): 135-156.

Andrew J. Elliot and Daniela Niesta, Romantic Red: Red Enhances Men's Attraction to Women . Journal of Personality and Social Psychology, v. 95, No. 5, (2008): 1150-1164.

Choungourian.A. Color Preferences and Cultural Variation. Perceptual and Motor Skills. 26. (1968):1203-1206.

Color the silent language. Paint \& Coatings Industry; Sep 2002; 18, 9; ABI/INFORM Trade \& Industry

Dee, J., \& Taylor, L. Colour therapy: The symbolism, use, and healing effects of colour. (Leicester, England: Silverdale Books, 2002).

Elliot, A. J., Maier, M. A., Moller, A. C., Friedman, R., \& Meinhardt, J. Color and psychological functioning: The effect of red on performance attainment. Journal of Experimental Psychology: General, 136, (2007): 154-168.

Hemphill, M. (1996). A note on adults' color-emotion associations. Journal of Genetic Psychology, 157, 275-280.

Greenfield, A. B. A perfect red: Empire, espionage, and the quest for the color of desire. (New York: Harper Collins,2005)

Rebecca L Alley. Thomas R Alley. The influence of physical state and color on perceived sweetness. The Journal of Psychology; (1998): 561. 
Valdez.P. \& Mehrabian.AEffect of Color on Emotions. Journal of Experimental Psychology. General, 123. (1994): 394-409.

Education JournalsCurrent Health 2. (1997).

Web

http://www.alfegh.com, accessed on 18 February 2012.

http://www.islamweb.net/newlibrary/display. See: Ibn ×ajar al-ÑAsqalÉnÊE, Fatí al-BÉrÊE, v.4, p.298.

http://www.colourtherapyhealing.com/colour_therapy/what_is_colour therapy.php, accessed on 23 February 2012.

http://www.colormatters.com/color-matters-for-kids/color-and-what-you-wear, accessed on 22 February 2012.

hhttp://www.empower-yourself-with-color-psychology.com/color-yellow.html, accessed on 23 February 2012.

http://www.empower-yourself-with-color-psychology.com/color-red.html, accessed on 23 February 2012.

http://www.islamqa.com/en/ref/110061, accessed on 23 February 2012.

http://www.empower-yourself-with-color-psychology.com/color-green.html, accessed on 23 February 2012.

http://www.empower-yourself-with-color-psychology.com/color-black.html, accessed on 23 February 2012.

http://www.empower-yourself-with-color-psychology.com/color-white.html, accessed on 23 February 2012.

http://www.empower-yourself-with-color-psychology.com/meaning-of-colors.html, accessed on 23 February 2012.

http://www.empower-yourself-with-color-psychology.com/cultural-color.html, accessed on 22 February 2012.

http://library.thinkquest.org/C004179/significance.htm, accessed on 22 February 2012.

http://muttaqun.com/malehijab.html, accessed on 22 February 2012.

http://www.sensationalcolor.com/color-messages-meanings/color-meaning-symbolism-psychology/allabout-the-color-white.html, accessed on 22 February 2012.

http://www.sensationalcolor.com/color-messages-meanings/color-meaning-symbolism-psychology/allabout-the-color-green.html, accessed on 22 February 2012.

http://en.wikipedia.org/wiki/Chromotherapy, accessed on 22 February 2012. 